\title{
Boccardia proboscidea and Boccardiella hamata (Polychaeta: Spionidae: Polydorinae), introduced mud worms new for the North Sea and Europe, respectively
}

\author{
FRANCIS KERCKHOF ${ }^{1}$ AND MARCO A. FAASSE ${ }^{2}$ \\ ${ }^{1}$ Royal Belgian Institute of Natural Sciences, Operational Directorate Natural Environment, Marine Ecology and Management \\ Section, 3e en 23e Linieregimentsplein, B-840o Oostende, Belgium, ${ }^{2}$ eCOAST Marine Research, PO Box 149, 4330 AC Middelburg \\ and Naturalis Biodiversity Center, PO Box 9517, 2300 RA Leiden, The Netherlands
}

\begin{abstract}
There is a worldwide concern about the expansion of non-indigenous species because they may threaten local biodiversity as some of them may successfully outcompete native species. We report on the presence of two introduced mud worm species, Boccardia proboscidea and Boccardiella hamata, in the southern North Sea, where the former species has been discovered on groynes along the Belgian coast and both species were detected among Pacific oysters Crassostrea gigas in the southwestern Dutch delta. Boccardia proboscidea is native to the North Pacific and was first detected in Europe along the Spanish Basque coast in 1996. Our record is the third for European waters and the first for the North Sea. Although B. proboscidea occurs in limited numbers and in ephemeral habitats along the Belgian coast, the species probably has established a permanent population, since it has been reported repeatedly after its first discovery in January 2011. Boccardiella hamata is native to the Atlantic and Gulf coasts of North America. This species has never been recorded from Europe before. Our research demonstrates that in under-studied habitats, such as man-made hard substrata, even well-established populations of newly introduced species may stay undetected. Due to a lack of monitoring of these particular habitats and insufficient knowledge about introduced biota, introduced species may pass unnoticed or may be overlooked for several years. A dedicated monitoring will be necessary to detect introduced species in an early stage. In view of the upcoming Marine Strategy Framework Directive requirements such monitoring will be inevitable.
\end{abstract}

Keywords: mud worms, Boccardia, Boccardiella, introduction, North Sea

Submitted 31 March 2014; accepted 30 June 2014

\section{INTRDDUCTION}

The risks associated with the introduction of marine species are now generally acknowledged (Carlton, 2002). Several national marine introduced species lists have been published (e.g. Eno et al., 1997). Kerckhof et al. (2007) provided a comprehensive list for Belgium that was actualized and extensively annotated by Vandepitte et al. (2012). Wolff (2005) did the same for The Netherlands.

The occurrence of so-called mud worms, i.e. the genus Polydora and related genera, often raises concerns in oyster culture as several species in this group drill holes in calcareous substrata, such as mollusc shells (Hoeksema, 1983; Bailey-Brock, 2000; Ruellet, 2004; Simon et al., 2010). They can also form dense tube mats covering large areas in polluted or deteriorated habitats, smothering other sessile invertebrates (e.g. Daro \& Polk, 1973; Jaubet et al., 2011). This was the reason for extensive research in the past in Belgium and The Netherlands (Korringa, 1951; Daro, 1969; Daro \& Polk,

Corresponding author:

F. Kerckhof

Email: f.kerckhof@mumm.ac.be
1973). However, for about half a century little or no attention has been paid to infestations of non-indigenous species such as shell-boring polychaetes on commercially harvested molluscs in Belgium and The Netherlands. In view of the problems with taxonomy and identification in this group of polychaetes and the high incidence of introductions worldwide (Hatton \& Pierce, 2013), a new investigation of mud worms in this region seemed worthwhile. We decided to sample habitats that non-indigenous polydorins were likely to prefer. In The Netherlands a quick survey of mud under wild Pacific oysters Crassostrea gigas (Thunberg, 1793) outside of culture plots was performed. In Belgium muddy turf of polydorin tubes on groynes, mainly of the native mud worm Polydora ciliata (Johnston, 1838), was sampled. During the analysis of our material Hatton \& Pierce (2013) had already proved that such a sampling strategy could yield important new results.

\section{MATERIALS AND METHODS}

\section{Sampling}

Samples were taken on the coast of Belgium and the southwest Netherlands in the Southern Bight of the North Sea 
(Figure 1). Along the Belgian coast sampling was conducted on groynes, man-made coastal defence structures of bluestone, built perpendicularly to the sandy coast (Figure 2). In January 2011 Polydora-turf (mainly Polydora ciliata) was collected from a large stone emerging at the seaward end of groyne no. 2 at Koksijde during spring tide low water (Figure 3). In August 2011 the intertidal marine growth on groyne no. 16 in Oostende (Raversijde) was sampled.

In September 2011, a further 3 groynes along the Belgian coast were sampled quantitatively, including the 2 groynes where Boccardia proboscidea had been noted during the two previous searches: 1 groyne in Koksijde (no. 6); 1 in Oostende Raversijde (no. 16); and 1 in Oostende Halve Maan (no. 3). Numbering of the groynes was according to the maps used by the Flemish Coastal Administration (Anonymous, 2010). Scrape samples with a known surface between 100 and $300 \mathrm{~cm}^{2}$ were taken distributed all over the length of the groyne.

The samples were randomly chosen in zones where B. proboscidea was expected. Bare areas, low tidal mussel beds and large sedentary animals such as Patella vulgata Linnaeus, 1758 were avoided. We only sampled the turf, consisting of young-of-the-year mussels, barnacles and sediment, with superficial green algae or Polydora colonies at the low water mark of spring tide. Material was scraped off with a putty knife and carefully collected for further processing in the laboratory.
In The Netherlands, five locations in the south-western delta area were chosen to survey (Table 1; Figure 1). Yerseke (eastern Scheldt estuary) was chosen because it is the centre of shellfish handling and trade. Borssele (western Scheldt estuary) was chosen because it is situated along the busy international shipping route to the port of Antwerp and cooling water discharge from its power plant causes artificial warming of the seawater. Vlissingen is situated along the same shipping route, but does not experience artificial warming. Zierikzee and the Goesse Sas (eastern Scheldt estuary) have no shellfish trade, nor artificial warming, nor international shipping, but are situated near outlets of canals used by inland and/or recreational shipping. At each location, on each date, 10 Pacific oysters were dislodged from boulders, occurring less than $1 \mathrm{~m}$ above mean low water and polychaete worms were collected, occurring in mud crevices on the underside of and between oysters.

\section{RESULTS}

In our samples, we identified two new species for the North Sea region namely Boccardia proboscidea (Hartman, 1940) and Boccardiella hamata (Webster, 1879).

Along the Belgian coast, Boccardia proboscidea was present on all 3 locations, always in small numbers (Table 1 ). Densities varied between 100 ind. $/ \mathrm{m}^{2}$ (Koksijde 2012) and 1250 ind. $/ \mathrm{m}^{2}$

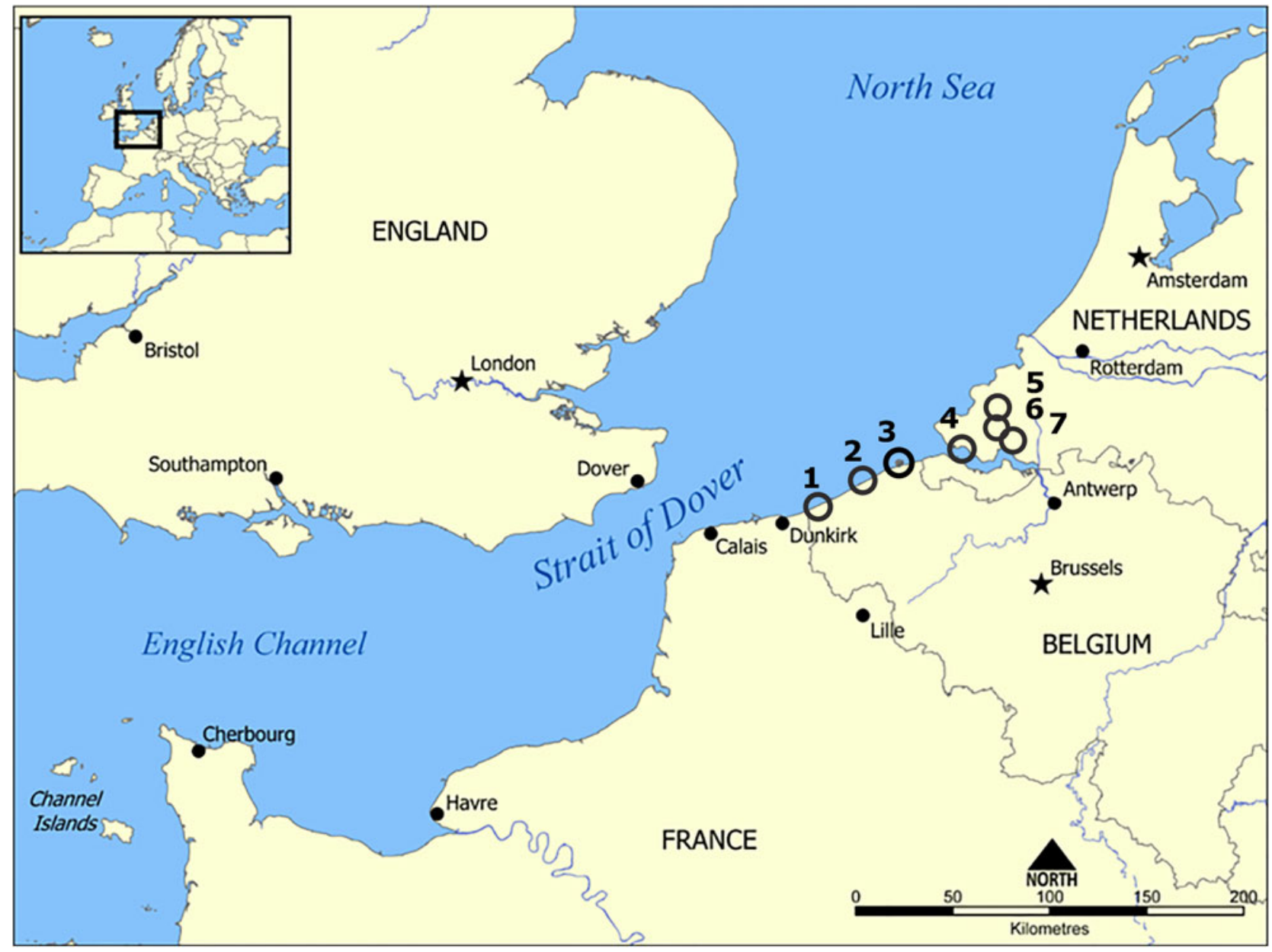

Fig. 1. Sampling locations in the Southern Bight of the North Sea, mentioned in this paper: 1, Koksijde; 2, Oostende; 3, Zeebrugge; 4, Vlissingen and Borssele; 5, Zierikzee; 6, Goesse Sas; 7, Yerseke. 


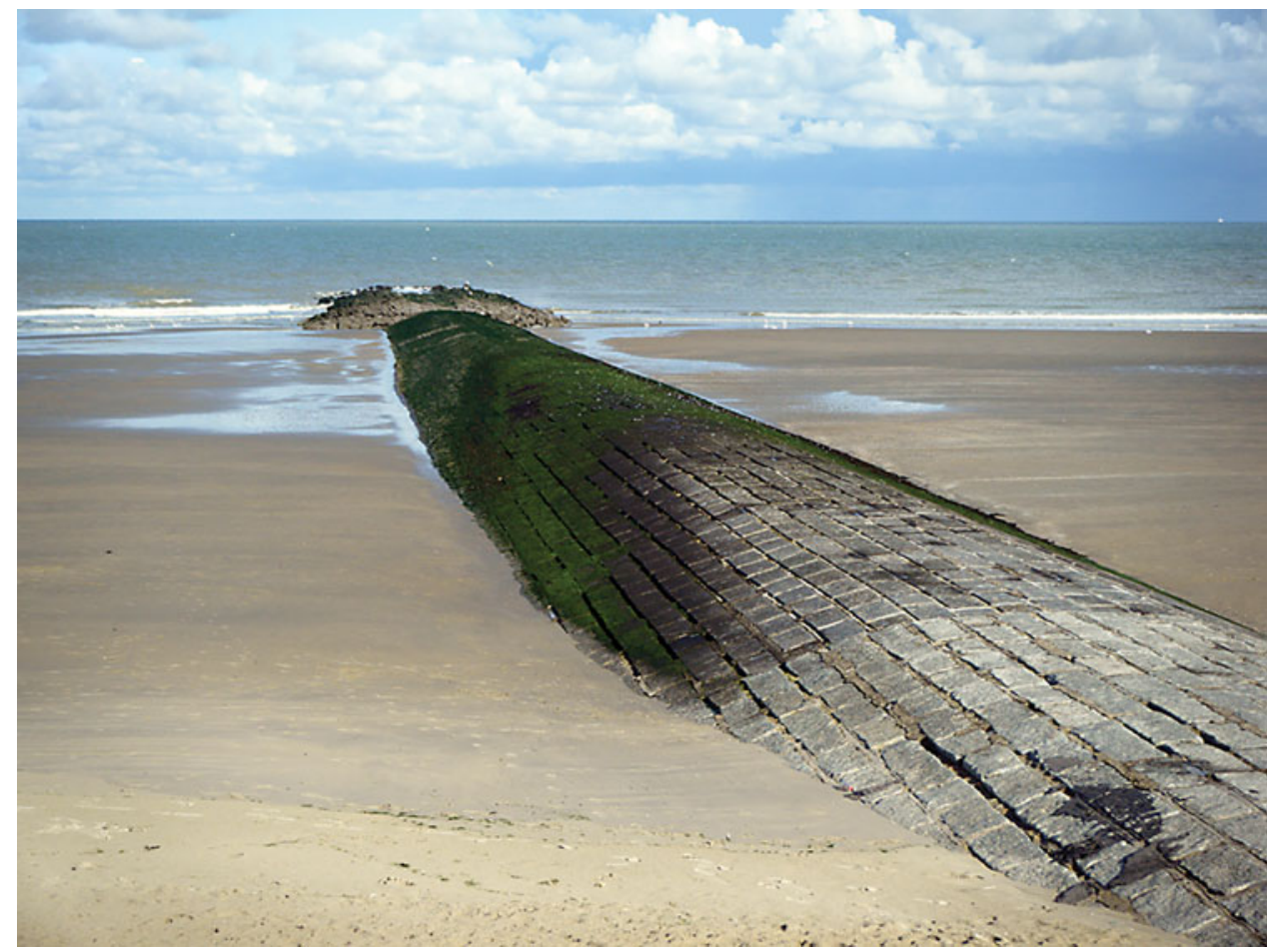

Fig. 2. Groyne no. 16 at Oostende (Raversijde), 18 September 2011.

(Oostende 2013). In Koksijde B. proboscidea was only present in the lower intertidal, in the Polydora turf, and it was not found in samples higher on the groyne (Ulva zone). In Oostende (both sites) B. proboscidea was present along the whole algae zone covering the groynes, where it sometimes was the only spionid. In The Netherlands B. proboscidea was present near Borssele, close to the cooling water discharge of a power plant, and near the Goesse Sas, a site without artificial warming. Boccardiella hamata was present at all sites (Zierikzee, the Goesse Sas, Yerseke and Vlissingen) except the site with artificial warming (Borssele). Densities were not measured as the occurrence of the mud worms was highly patchy. 5-10 individuals of $B$. proboscidea were

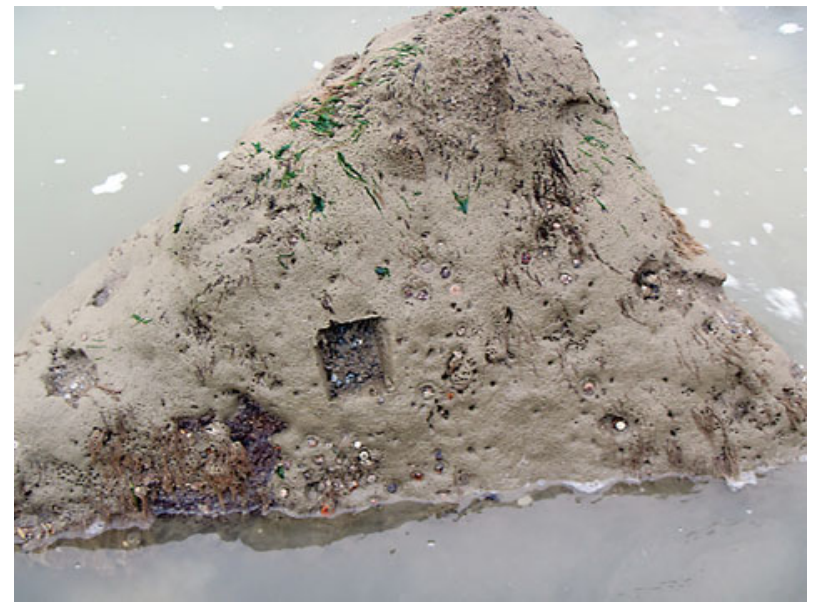

Fig. 3. Large stone at the seaward end of groyne no. 6 at Koksijde: covered with polydorins in tubes and sampled on 23 July 2013 . collected from mud under 10 oysters, and of B. hamata 2-5 individuals were collected from 10 oysters (Table 1 ).

Several specimens of $B$. proboscidea collected on 23 July 2013 are lodged in the Reference collection of the Operational Directorate Natural Environments (OD) of the Royal Belgian Institute of Natural Sciences at Oostende under registration number TRC 16. Three specimens of Boccardia proboscidea collected at the Goesse Sas on 8 July 2013 have been deposited in the collection of Naturalis Biodiversity Center, Leiden, with registration number RMNH.VER.19904; 3 specimens of Boccardiella hamata (Yerseke, 16 July 2013) have been deposited in the same collection with registration number RMNH.VER.19902. Three further specimens of B. hamata have been deposited in the reference collection of the OD under registration number TRC 60.

\section{DISCUSSIDN}

\section{Species identification}

Boccardia proboscidea (Hartman, 1940) Synonym Polydora californica Treadwell, 1914

Identification of this species with a recent regional polychaete identification manual (Hartmann-Schröder, 1996) readily points to Boccardiella ligerica (Ferronière, 1898) due to the gills on chaetigers 2, 3 and 4. Identification with the older and more southerly-oriented manual of Fauvel (1927) points to Boccardia polybranchia (Haswell, 1885). Martínez et al. (2006) provide a key to Boccardia species recorded from the Atlantic, including $B$. proboscidea, which highlights the short notopodial chaetae on the first chaetiger of $B$. proboscidea (Figure 4), that are lacking in B. polybranchia. 
Table 1. Samples taken to collect 'mud worms' and densities or numbers recorded; at locations in The Netherlands (Goesse Sas, Vlissingen, Borssele, Yerseke and Zierikzee) no densities were determined.

\begin{tabular}{|c|c|c|c|c|}
\hline Location & Date & Species & Zone & Number or density \\
\hline \multirow[t]{6}{*}{ Koksijde groyne 6} & $23 / 01 / 2011$ & Boccardia proboscidea & MLWS-ELWS & Present \\
\hline & $01 / 10 / 2011$ & B. proboscidea & MLLWS-ELWS+MTL-MLWS & $100 / \mathrm{m}^{2} \mathrm{o} ; \mathrm{o} ; \mathrm{o} / \mathrm{m}^{2}$ \\
\hline & $16 / 10 / 2011$ & B. proboscidea & MLWS-ELWS & $450 / \mathrm{m}^{2}$ \\
\hline & $29 / 10 / 2011$ & B. proboscidea & MLWS-ELWS & $333 / \mathrm{m}^{2}$ \\
\hline & $19 / 09 / 2012$ & B. proboscidea & MLWN-MLWS & $50 / \mathrm{m}^{2}$ \\
\hline & $23 / 07 / 2013$ & B. proboscidea & MLWS-ELWS & $100 ; 300 ; 400 ; 800 / \mathrm{m}^{2}$ \\
\hline \multirow[t]{4}{*}{ Oostende (Raversijde) groyne 16} & $21 / 08 / 2011$ & B. proboscidea & MTL-MLWN & Present \\
\hline & $08 / 10 / 2011$ & B. proboscidea & MTL-MLWN & $133 ; 466 / \mathrm{m}^{2}$ \\
\hline & $15 / 09 / 2012$ & B. proboscidea & MTL-MLWN & $266 / \mathrm{m}^{2}$ \\
\hline & $18 / 08 / 2013$ & B. proboscidea & MTL-MLWN & $1250 / \mathrm{m}^{2}$ \\
\hline \multirow[t]{2}{*}{ Oostende (Halve Maan) groyne 3} & $15 / 10 / 2011$ & B. proboscidea & MTL-MLWN & $133 ; 33 / \mathrm{m}^{2}$ \\
\hline & $18 / 08 / 2013$ & B. proboscidea & MTL-MLWN & $0 ; \mathrm{o} / \mathrm{m}^{2}$ \\
\hline \multirow[t]{4}{*}{ Goesse Sas } & $05 / 07 / 2013$ & B. proboscidea & MTL-MLWN & $\sim_{5}$ \\
\hline & $06 / 07 / 2013$ & B. proboscidea & MTL-MLWN & $\sim_{5}$ \\
\hline & $08 / 07 / 2013$ & B. proboscidea & MTL-MLWN & $\sim_{10}$ \\
\hline & $08 / 07 / 2013$ & Boccardiella hamata & MTL-MLWN & $\sim_{5}$ \\
\hline Vlissingen & $10 / 07 / 2013$ & B. hamata & MTL-MLWN & 2 \\
\hline Borssele & $13 / 07 / 2013$ & B. proboscidea & MTL-MLWN & $\sim_{5}$ \\
\hline \multirow[t]{2}{*}{ Yerseke } & $16 / 07 / 2013$ & B. hamata & MTL-MLWN & 9 \\
\hline & $18 / 07 / 2013$ & B. hamata & MTL-MLWN & $\sim_{5}$ \\
\hline Zierikzee & $31 / 08 / 2013$ & B. hamata & MTL-MLWN & 4 \\
\hline
\end{tabular}

MLWS, mean low water spring; ELWS, extreme low water spring; MTL, mean tide level; MLWN, mean low water neap.

Boccardia proboscidea further differs from other Boccardia species recorded from the Atlantic, in the bristle-tipped special chaetae of chaetiger 5 without subdistal bosses (Figure 5) and the undivided prostomium. In these characters B. proboscidea (Figure 6) also differs from Boccardiella ligerica (Hartman, 1940; Blake \& Kudenov, 1978; Martínez et al., 2006). The genera Boccardia Carazzi, 1893 and Boccardiella Blake \& Kudenov, 1978 differ in the presence of branchiae on the first setigers: in Boccardiella they are present on setigers 2, 3 and 4, in Boccardia branchiae are present only on setigers 2 and 3 (Blake \& Kudenov, 1978).

Boccardiella hamata (Webster, 1879)

Synonym Boccardia uncata Berkeley, 1927

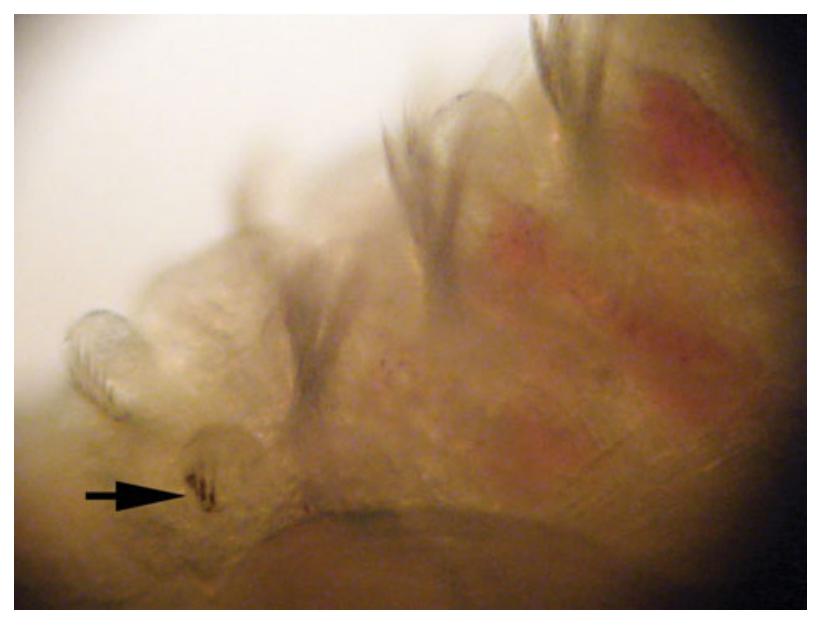

Fig. 4. Boccardia proboscidea, Oostende (Raversijde), 21 August 2011: notopodial chaetae of first chaetiger (arrow).
Using European polychaete identification manuals (Fauvel, 1927; Hartmann-Schröder, 1996) this species will be identified as $B$. ligerica. However, the latter species is described as a strict brackish water species (e.g. Blake, 1983), whereas B. hamata is common in fully marine as well as estuarine conditions (Blake, 1966). There are at least two clear morphological differences (Blake, 1966; Radashevsky, 1993). In the posterior region a series of segments with large re-curved notopodial hooks is present. In $B$. hamata these hooks are accompanied by a few thin capillary chaetae and a row of acicular spines (Figure 7 ).

In $B$. ligerica these acicular spines are absent (Blake \& Woodwick, 1971; Hartmann-Schröder, 1996). Furthermore, the anal cirri of both species are clearly different. The pygidium of $B$. ligerica bears two more or less elongated processes, whereas the pygidium of $B$. hamata is provided with two short and flat flaps, each with a short and thin process, that is directed more or less laterally (Figure 8). A species with a similar pygidium is Boccardiella bihamata Blake \& Kudenov, 1978, described from Australia. Boccardiella bihamata differs from both species concerned in the possession of unidentate neuropodial hooks in the posterior region with re-curved notopodial hooks (Blake \& Kudenov, 1978).

\section{Historical background}

After the research of Korringa (1951) and Hoeksema (1983) no investigations on mud worms in The Netherlands have been conducted. Daro $(1969,1970)$ was the first and only to study mud worms in Belgium.

The main tube-building polychaete species forming dense tube-mats on artificial hard substrata in northern European intertidal habitats used to be Polydora ciliata (see Daro \& Polk, 1973). Our current knowledge about the occurrence of species of this group in the Southern Bight of the North Sea is certainly flawed. Intertidal man-made hard substrata, although increasing are little-studied habitats, which means 


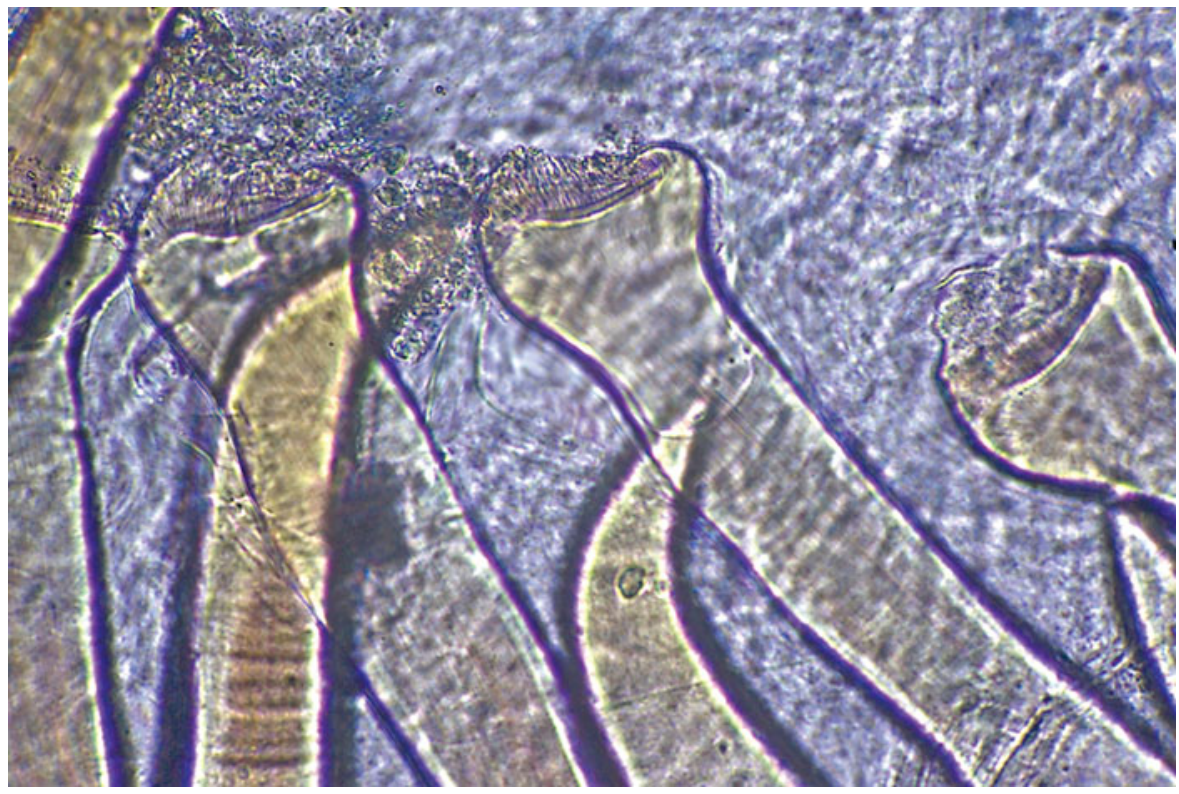

Fig. 5. Boccardia proboscidea, Goesse Sas, 8 July 2013: special chaetae of fifth chaetiger (bristle-tipped without bosses).

that species present may remain unnoticed for a long time. Moreover, in the busily navigated and cultivated coastal areas of the southern North Sea, species from all over the world may show up, that are not mentioned in European identification manuals, which may lead to misidentifications (e.g. Kerckhof \& Cattrijsse, 2001; Faasse \& van Moorsel, 2002).

In Belgium, Daro (1969) and Daro \& Polk (1973) studied the spionid fauna (mainly Polydora ciliata) in some detail as this species was considered a pest for oyster culture and thus a reason for concern. Daro $(1969,1970)$ was also the first to study the artificial habitats of the groynes along the Belgian coast. Some thirty years later, during the early 200os, the groynes and certain harbour environments all along the Belgian coast were addressed in a more

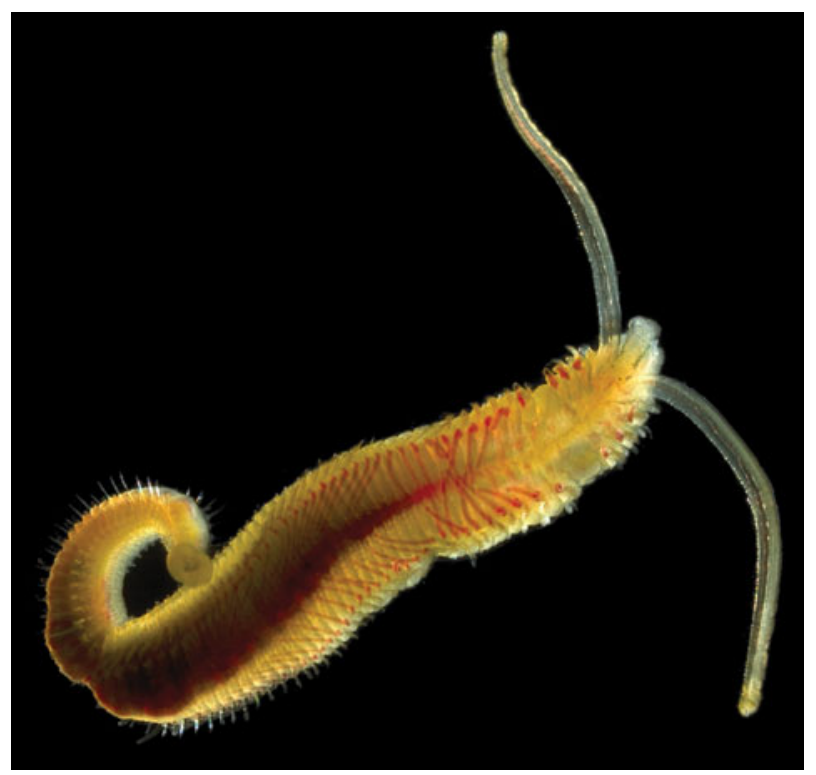

Fig. 6. Boccardia proboscidea, Oostende (Raversijde), 24 September 2011 , habitus: prostomium undivided, with black pigment laterally (photograph by Jan Haelters Royal Belgian Institute of Natural Sciences). comprehensive study aimed to gain insight into the biological value of these man-made structures (Engledow et al., 2001; Volckaert et al., 2003). In this study, sampling was done in autumn 2000 and during 2001, and included the groyne no. 6 at Koksijde but not the groynes around Oostende included in our study. Only Engledow et al. (2001) and Volckaert et al. (2003) mention the presence of a second polydorin from the coast of Belgium, namely Boccardiella ligerica. It was first encountered at a site in the harbour of Zeebrugge, with 51 ind. $/ \mathrm{m}^{2}$ (Engledow et al., 2001). In the succeeding study (Volckaert et al., 2003) the presence of B. ligerica was also mentioned from groynes along the coast, in fully marine conditions, including groyne Koksijde no. 6 of our study and a sheltered site inside of the outer harbour of Zeebrugge.

We had reason to believe that Engledow et al. (2001) and Volckaert et al. (2003) were probably not dealing with Boccardiella ligerica. Indeed, when we first encountered B. proboscidea and attempted to identify this species with

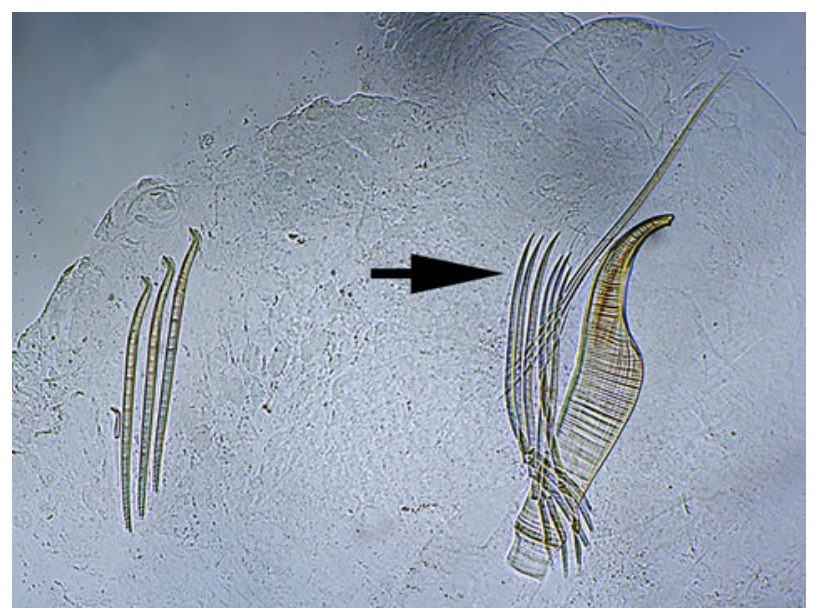

Fig. 7. Boccardiella hamata, Yerseke, 18 August 2013: neurochaeta (left) and notochaeta (right) of 27 th chaetiger; arrow, row of acicular spines. 


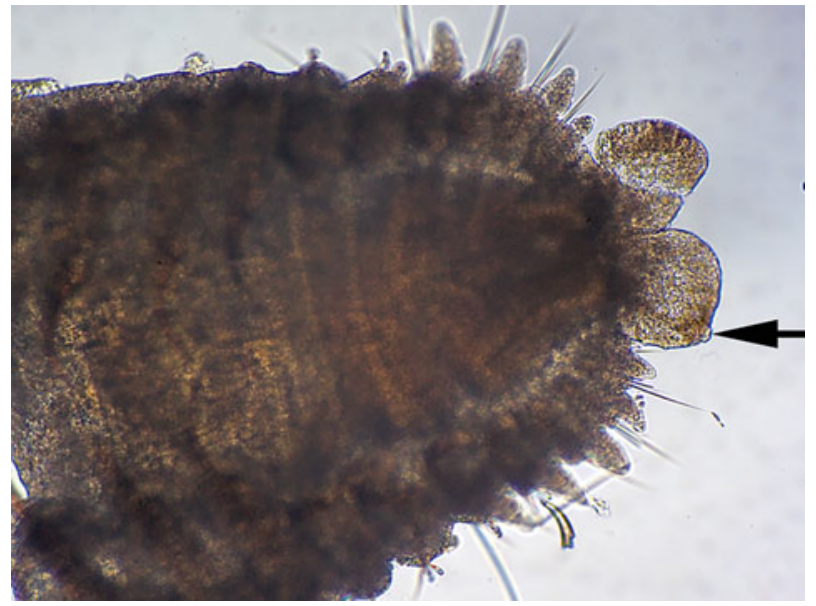

Fig. 8. Boccardiella hamata, Goesse Sas, 6 July 2013: pygidium with flat flaps; lateral processes of flaps (arrow) strongly contracted during fixation.

the regional identification manual (Hartmann-Schröder, 1996) we ended up on B. ligerica (see Species identification). Part of the material of the study by Volckaert et al. (2003) was still present in the collections of the Marine Biology Research Group at Ghent University and we were able to check the available samples identified as B. ligerica from Koksijde and Zeebrugge, all collected in November 2001. Indeed the specimens from Koksijde all proved to belong to $B$. proboscidea. However, the Zeebrugge sample, collected amongst Pacific oysters (Crassostrea gigas Thunberg, 1793) and thus a different habitat than the groynes, turned out to be $B$. hamata. Recently $B$. ligerica was also identified in macrobenthic samples taken in the vicinity of a wind turbine on the Thornton Bank (Belgium) (Degraer et al., 2013), but re-examination of the specimen revealed it belonged to the genus Dipolydora Verrill, 1881.

\section{Distribution and dispersal}

The genera Boccardia and Boccardiella have a predominantly Pacific distribution with few species in the north-east Atlantic. Fauvel (1927) mentions Boccardia polybranchia (Haswell, 1885) (as Polydora (Boccardia) polybranchia) and Boccardiella ligerica (as Polydora (Boccardia) ligerica). Recently Guérin (1990) described a new species, Boccardia semibranchiata, from oyster parks in Normandy. Finally, Boccardia proboscidea was recorded from the Atlantic Iberian coast (Martínez et al., 2006) and recently from the north-west of Scotland (Hatton \& Pierce, 2013).

\section{Boccardia proboscidea}

Boccardia proboscidea was originally described from California (Hartman, 1940). The North Pacific coastlines of Japan and North America are considered to be the original distribution range of $B$. proboscidea (see Simon et al., 2010). The occurrence in Hawai'i (Bailey-Brock, 2000), Australia (Blake \& Kudenov, 1978), New Zealand (Read, 2004), South Africa (Simon et al., 2010), Argentina (Jaubet et al., 2011), Maine (Bailey-Brock, 2000), Spain (Martínez et al., 2006) and Scotland (Hatton \& Pierce, 2013) is ascribed to humanmediated introductions, mainly related to transfers of cultured shellfish. Boccardia proboscidea was inadvertently transported to South Africa on Haliotis rufescens Swainson, 1822, which was imported from California in the late 1980s (Simon et al., 2010). Introduction to Hawai'i occurred with shipments of oysters Ostrea edulis Linnaeus, 1758 from Maine, on the Atlantic coast of North America (Bailey-Brock, 2000). Vectors of introduction to other regions have not been established with certainty.

The European records known to us are by Martínez et al. (2006), who reported B. proboscidea from the Spanish coast of the Gulf of Biscay from 1996 onwards, and by Hatton \& Pierce (2013) who reported the species from the Isle of Skye in Scotland in 2011 and 2013.

Boccardia proboscidea has now an almost cosmopolitan distribution in temperate waters. Only records from the south-east Pacific are lacking.

\section{Boccardiella hamata (Webster, 1879)}

Boccardiella hamata was described from the Atlantic coast of North America and was later reported from the Gulf coast (Dean \& Blake, 1966), the Pacific coast of North America (Blake, 1966) and from the north-west Pacific (Japan) (Dean \& Blake, 1966; Radashevsky, 1993). We could not find any references to introduction of $B$. hamata with imported shellfish or other vectors. As far as we know, the species has not been reported from the north-east Atlantic before. Boccardiella hamata is now distributed in temperate waters all over the northern hemisphere. Blake (1966) synonymized Polydora uncatiformis Monro, 1938 from South America (Uruguay) with $B$. hamata. However, according to Blake \& Kudenov (1978), this synonymization is erroneous and $P$. uncatiformis is a synonym of B. ligerica.

\section{Possible vectors of transportation}

There has been a significant increase in the incidence of marine biological invasions as human-mediated vectors, shipping and aquaculture in particular, continuously gain in importance (e.g. Carlton, 1985; Carlton \& Geller, 1993). Along the coast of Belgium and The Netherlands both vectors are equally important, with two large ports, Antwerp and Rotterdam, and abundant shellfish culture and trade, resulting in numerous introductions by both vectors (Wolff, 2005; Kerckhof et al., 2007). In the case of Boccardia proboscidea and Boccardiella hamata we cannot indicate the vector. Both species occur along shipping routes (Borssele and Vlissingen along the western Scheldt) and near shellfish culture areas (Zierikzee, Goesse Sas and Yerseke along the eastern Scheldt). Both species obviously may have been introduced with shellfish, possibly elsewhere in the region, but transport in hull fouling or as larvae in ballast water cannot be ruled out. After an initial introduction, secondary expansion may have taken place, enlarging the distribution range in the introduced region. The increased presence of man-made structures may have provided additional opportunities to settle and to establish permanent populations in the southern North Sea region.

\section{Habitat and ecology}

Polydorin species can either construct self-excavated burrows inside calcareous substrata, or live in mud-filled crevices or burrows or live in soft substrata. Behavioural differences in 
crawling, palp activity and tube construction between boring and non-boring polydorin species have been reported by Sato-Okoshi \& Okoshi (1997). The non-boring Boccardia proboscidea is a rapid crawler with thick blood vessels in the branchiae that is able to quickly hide itself and construct a new tube when removed from its habitat (Sato-Okoshi, 2000; authors, personal observations), while the borer in calcareous substrata B. berkeleyorum Blake \& Woodwick, 1971 is a slow crawler with thinner blood vessels in the branchiae, unable to form a new burrow or hide itself in mud deposits (Sato-Okoshi \& Okoshi, 1997). Sato-Okoshi \& Okoshi (1997) suggest that the slower palp activity, the slower crawling and the inability to hide of mud-boring species are related to their stable habitat in calcareous substratum burrows.

Boccardia proboscidea exhibits a wide ecological amplitude. It creates burrows of varying shape and size that are made in muddy and sandy sediments or in existing mud-filled burrows and crevices in soft rock and mollusc shells. It can also be found among encrusting algae or amongst mussels (Hartman, 1940; Woodwick, 1963; Gibson et al., 1999; Read, 2004; Ruellet, 2004; Martínez et al., 2006; Simon et al., 2009). Boccardia proboscidea is known as an indicator species for organic enrichment of sediments and is often numerically dominant (Johnson, 1970; Blake \& Kudenov, 1978; Jaubet et al., 2011). In The Netherlands, it occurs at a location with artificially warmed seawater (Borssele), although it is not restricted to that location. The habitat where B. proboscidea was found in Belgium is on groynes, in Polydora ciliata patches in the lower intertidal zone and higher, amongst barnacles, green algae and small mussels and there it was often the only spionid attaining its largest densities. This habitat is ephemeral, i.e. during winter most of the biota on the groynes disappears, leaving a bare substratum until spring when recolonization starts. This leaves the question of the origin of the new settlers.

Boccardiella hamata occurs in a variety of muddy estuarine habitats, amongst tubes of fine sediment on rocks between bases of the barnacle Balanus improvisus on the west coast of North America (Dean \& Blake, 1966). These same authors report this species from galleries of shells on the east and Gulf coasts and from a muddy flat between crevices of rock in Japan. In Peter the Great Bay B. hamata occurs in estuaries in shallow water, reportedly boring into shells, mainly of the Pacific oyster and also inhabiting mud tubes on the exterior surface of the oysters (Radashevsky, 1993). Blake (1966) reports the species from British Columbia to Baja California from oyster beds, estuarine mud, Dodecaceria sp. Örsted, 1843 masses, and other littoral conditions. On the east and Gulf coasts it penetrates oyster and gastropod shells, according to Blake (1966). In central California it occurs in accumulated sand in algal holdfasts and in hermit crab shells, together with other polydorins (Blake, 1966). According to Sato-Okoshi \& Okoshi (1997) B. hamata does not bore. The latter authors refer to its occurrence in mud in the crevices of Pacific oysters in Japan or mud crevices in sandstone rocks in Canada. The habitat where B. hamata was found in Belgium, amongst Pacific oysters, is similar to the habit in The Netherlands.

\section{Reasons for success}

Larval development in mud worms is different between species. In Boccardia proboscidea development even differs within one population (Gibson et al., 1999). This species is able to produce non-viable eggs, which serve as food for developing larvae in the same egg capsule, resulting in rapid growth and offspring hatching as juveniles eleven days after oviposition. On the other hand, planktotrophic larvae may be produced, whose development to juveniles requires $19-36$ days from oviposition (Gibson et al., 1999). The rapid growth of the first type of offspring enables quick growth of local populations. The pelagic planktonic development of the second type, the planktotrophic larvae, takes about a month and promotes dispersal over larger areas. This so-called poecilogonous development may enhance the success of the species in new areas. For Boccardiella hamata only planktotrophic development is known (Dean \& Blake, 1966), enabling expansion over larger areas, although build-up of local populations may take more time than in brooding species.

\section{Possible effects and concerns}

Several polydorins cause severe effects to their calcareous molluscan hosts. Many species are known to drill holes in bivalve shells, causing blisters, and consequently a substantial decrease in growth and survival (e.g. Sato-Okoshi \& Okoshi, 1997). Boccardia proboscidea has been described as a secondary borer (Simon et al., 2009). However, some polydorins behave differently across various regions, boring in shells in one region and not boring, but tube-building, in another (Radashevsky \& Pankova, 2013). Shell-boring of Boccardiella hamata is known from the Atlantic coast of North America (Blake, 1966). Therefore, the introduction of both species to the North Sea region is of concern for shellfish culture and wild populations of shelled molluscs. Furthermore, B. proboscidea may be a threat to local biodiversity as this species is able to form dense mats of aggregated tubes in situations of organic enrichment, smothering other invertebrates (Johnson, 1970; Blake \& Kudenov, 1978; Jaubet et al., 2011). Therefore it is advisable to follow the development and dispersal of the introduced polydorins.

\section{Conclusions and relevance of monitoring of hard substrata}

Our present records of two non-indigenous mud worms detected in the southern North Sea within a few years do not necessarily imply the occurrence of recent invasions. In view of the low survey effort in artificial hard substrata habitats and the absence of dedicated mud worm research during more than half a century it is impossible to estimate the years of introduction, which may be any year between the 1950 and the present. Non-native species collected during surveys that are not focused on introductions are usually misidentified as morphologically similar native species when only local identification keys are used (e.g. Kerckhof \& Cattrijsse, 2001; Faasse $\&$ van Moorsel, 2002). In this context it is worth noting that in a limited period of time B. proboscidea was reported from such distant European regions as Northern Spain (1996-1997) (Martínez et al., 2006), north-west Scotland (2011) (Hatton $\&$ Pierce, 2013) and the southern North Sea (2001 and 2011-2013) (this study). Although Ruellet (2004) did not report the species from the Normandy coast in his study performed in 2000-2003, the species may presently be widespread in several regions of the north-east Atlantic, but not 
recognized. This is illustrated here by the discovery of both species in previously collected samples from the Belgian coast, documenting an earlier presence in the North Sea. We emphasize the fact that deviations from morphological descriptions, especially when accompanied by divergences in habitat preferences, deserve further study using worldwide identification literature. We particularly emphasize the importance of keeping voucher material.

Currently no regular research programmes to monitor intertidal macrobenthic hard substratum communities are conducted in Belgium or The Netherlands. Published reports on surveys aiming at the possible presence of non-native species are incidental (e.g. Gittenberger et al., 2010). Although softbottoms constitute the original biotope in this region and these still cover the largest area, the increasing presence of man-made structures and altered environments creates opportunities for introduced species. Neglect of hard substrata poses risks to shellfish culture, fisheries and the hard-substratum communities themselves. Even quick surveys of hard substrata apparently yield economically and ecologically relevant results. In view of the European Union Marine Strategy Framework Directive a proper monitoring of hard substratum communities is indispensable, especially as the area of hard substrata grows quickly due to harbour development, coastal defence works, wind farms and other man-made constructions.

\section{ACKNDWLEDGEMENTS}

We thank Professor Dr Magda Vincx, head of the Marine Biology Research Group at Ghent University, for giving us access to the earlier samples and we acknowledge various colleagues and an anonymous referee for valuable comments on earlier versions of this paper.

\section{REFERENCES}

Anonymous (2010) Plan van de Vlaamse Kust. Agentschap voor Maritieme Dienstverlening en Kust. Afdeling Kust.

Bailey-Brock J.H. (2000) A new record of the polychaete Boccardia proboscidea (Family Spionidae), imported to Hawai'i with oysters. Pacific Science 54, 27-30.

Blake J.A. (1966) On Boccardia hamata (Webster), new combination (Polychaeta: Spionidae). Bulletin of the Southern California Academy of Sciences 65, 176-184.

Blake J.A. (1983) Polychaetes of the family Spionidae from South America, Antarctica, and adjacent seas and islands. Biology of the Antarctic Seas XIV. Antarctic Research Series 39, 205-288.

Blake J.A. and Kudenov J.D. (1978) The Spionidae (Polychaeta) from south-eastern Australia and adjacent areas with a revision of the genera. Memoirs of the National Museum of Victoria 39, 171-280.

Blake J.A. and Woodwick K.H. (1971) A review of the genus Boccardia Carazzi (Polychaeta: Spionidae) with descriptions of two new species. Bulletin of the Southern Californian Academy of Sciences 70, $31-42$.

Carlton J.T. (1985) Transoceanic and interoceanic dispersal of coastal marine organisms: the biology of ballast water. Oceanography and Marine Biology: an Annual Review 23, 313-371.

Carlton J.T. (2002) Bioinvasion ecology: assessing invasion impact and scale. In Leppäkoski E., Gollasch S. and Olenin S. (eds) Invasive aquatic species of Europe: distribution, impact and management. Dordrecht, The Netherlands: Kluwer Academic Publishers, pp. 7-19.

Carlton J.T. and Geller J.B. (1993) Ecological roulette: the global transport of nonindigenous marine organisms. Science 261, 78-82.

Daro M.H. (1969) Etude écologique d'un brise-lames de la côte beIge. I Description et zonation des organismes. Annales de la Société Royale Zoologique de Belgique 99, 111-152.

Daro M.H. (1970) Etude écologique d'un brise-lames de la côte belge-II. Biologie et développement saisonnier des espèces. Annales de la Société Royale Zoologique de Belgique 100, 159-190.

Daro M.H. and Polk P. (1973) The autecology of Polydora ciliata along the Belgian coast. Netherlands Journal of Sea Research 6, 130-140.

Dean D. and Blake J.A. (1966) Life-history of Boccardia hamata (Webster) on the east and west coasts of North America. Biological Bulletin. Marine Biological Laboratory, Woods Hole 130, 316-330.

Degraer S., Brabant R. and Rumes B. (eds) (2013) Environmental impacts of offshore wind farms in the Belgian part of the North Sea: learning from the past to optimise future monitoring programmes. Brussels: Royal Belgian Institute of Natural Sciences (RBINS), Operational Directorate Natural Environment, Marine Ecology and Management Section, $239 \mathrm{pp}$.

Engledow H., Spanoghe G., Volckaert A., Coppejans E., Degraer S., Vincx M. and Hoffman M. (2001) Onderzoek naar de fysische karakterisatie en de biodiversiteit van strandhoofden en andere harde substraten langs de Belgische kust. Eindrapport in opdracht van het Min. Vlaamse gemeenschap, Dept. Leefmilieu en Infrastructuur, Afd. Waterwegen en Zeewezen, 109 pp.

Eno N.C., Clark R.A. and Sanderson W.G. (1997) Non-native marine species in British waters: a review and directory. Peterborough, UK: Joint Nature Conservation Committee, 152 pp.

Faasse M.A. and van Moorsel G.W.N.M. (2002) The North-American amphipods, Melita nitida Smith, 1873 and Incisocalliope aestuarius (Watling \& Maurer, 1973) (Crustacea: Amphipoda: Gammaridea), introduced to the Western Scheldt estuary (The Netherlands). Aquatic Ecology 32, 13-22.

Fauvel P. (1927) Polychètes sédentaires. Addenda aux errantes, Archiannélides, Myzostomaires. Paris: Paul Lechevalier. [Faune de France no. 16.]

Ferronnière G. (1898) Contribution a l'etude de la faune de la Loireinferieure (Polygordiens, Spionidiens, Nemertiens). Bulletin de la Société des Sciences Naturelles de l'Ouest de la France 8, 101-115.

Gibson G., Paterson I., Taylor H. and Woolridge B. (1999) Molecular and morphological evidence of a single species, Boccardia proboscidea (Polychaeta) with multiple development modes. Marine Biology 134, $743-751$.

Gittenberger A., Rensing M., Stegenga H. and Hoeksema B. (2010) Native and non-native species of hard substrata in the Dutch Wadden Sea. Nederlandse Faunistische Mededelingen 33, 21-75.

Guérin J.P. (1990) Description d'une nouvelle espèce de spionidé (Annélides, Polychètes) Boccardia semibranchiata. Annales de l'Institut Océanographique 66, 37-45.

Hartman O. (1940) Boccardia proboscidea, a new species of spionid worm from California. Journal of the Washington Academy of Sciences 30, $382-387$

Hartmann-Schröder G. (1996) Annelida, Borstenwürmer, Polychaeta. Jena: Gustav Fischer. [Die Tierwelt Deutschlands no. 58.]

Haswell W.A. (1885) Jottings from the Biological laboratory of Sydney University. 1. On a destructive parasite of the rock oyster. Proceedings of the Linnean Society of New South Wales 10, 273-275. 
Hatton J. and Pearce B. (2013) The first documented record of the non-native spionid Boccardia proboscidea in UK waters. Marine Biodiversity Records 6, e101. doi:10.1017/S1755267213000730.

Hoeksema B.W. (1983) Excavation patterns and spiculae dimensions of the boring sponge Cliona celata from the SW Netherlands. Senckenbergiana Maritima 15, 55-85.

Jaubet M.L., de los Ángeles Sánchez M., Rivero M.S., Garaffo G.V., Vallarino E.A. and Elías R. (2011) Intertidal biogenic reefs built by the polychaete Boccardia proboscidea in sewage-impacted areas of Argentina, SW Atlantic. Marine Ecology 32, 188-197.

Johnson R.G. (1970) Variations in diversity within benthic marine communities. American Naturalist 104, 285-300.

Johnston G. (1838) Miscellanea Zoologica Ariciidae. Magazine of Zoology and Botany, Edinburgh 2, 63-73.

Kerckhof F., Haelters J. and Gollasch S. (2007) Alien species in the marine and brackish ecosystem: the situation in Belgian Waters. Aquatic Invasions 2, 243-257.

Kerckhof F. and Cattrijsse A. (2001) Exotic Cirripedia (Balanomorpha) from buoys off the Belgian coast. Senckenbergiana Maritima 31, 245-254.

Korringa P. (1951) The shell of Ostrea edulis as a habitat. Archives Néerlandaises de Zoologie 10, 32-152.

Martínez J., Adarraga I. and López E. (2006) Nuevos datos del género Boccardia Carazzi, 1893 (Polychaeta: Spionidae) para la península Ibérica y el océano Atlántico. Boletín-Instituto Español de Oceanografía 22, 53-64.

Radashevsky V.I. (1993) Revision of the genus Polydora and related genera from the North West Pacific (Polychaeta: Spionidae). Publications of the Seto Marine Biological Laboratory 36, 1-60.

Radashevsky V.I. and Harris L.H. (2010) Case 3520 Boccardia proboscidea Hartman, 1940 (Annelida, Spionidae): proposed conservation of the specific name. Bulletin of Zoological Nomenclature 67, 203-210.

Radashevsky V.I. and Pankova V.V. (2013) Shell-boring versus tube-dwelling: is the mode of life fixed or flexible? Two cases in spionid polychaetes (Annelida, Spionidae). Marine Biology. doi: 10.1007/s00227-013-2214-8.

Read G.B. (2004) Guide to New Zealand shell polychaetes. Available at: http://www.annelida.net/nz/Polychaeta/Family/Spionidae/boccardiaproboscidea.htm (accessed 26 July 2013).

Ruellet T. (2004) Infestation des coquilles d'huitres Crassostrea gigas par les polydores en Basse-Normandie: recommandations et mise au point d'un traitement pour réduire cette nuisance. $\mathrm{PhD}$ thesis. Université de Caen/Basse-Normandie.

Sato-Okoshi W. (2000) Polydorid species (Polychaeta: Spionidae) in Japan, with descriptions of morphology, ecology, and burrow structure. 2. Non-boring species. Journal of the Marine Biological Association of the United Kingdom 80, 443-456.

Sato-Okoshi W. and Okoshi K. (1997) Survey of the genera Polydora, Boccardiella and Boccardia (Polychaeta, Spionidae) in Barkley Sound (Vancouver Island, Canada), with special reference to boring activity. Bulletin of Marine Science 60, 482-493.

Simon C.A., Thornhill D.J., Oyarzun F. and Halanych K.M. (2009) Genetic similarity between Boccardia proboscidea from Western North America and cultured abalone, Haliotis midae, in South Africa. Aquaculture 294, 18-24.

Simon C.A., Worsfold T.M., Lange L. and Sterley J. (2010) The genus Boccardia (Polychaeta: Spionidae) associated with mollusc shells on the south coast of South Africa. Journal of the Marine Biological Association of the United Kingdom 90, 585-598.

Vandepitte L., De Pooter D., Lescrauwaet A.-K., Fockedey N. and Mees J. (eds) (2012) Niet-inheemse soorten van het Belgisch deel van de Noordzee en aanpalende estuaria. VLIZ Special Publication 59. VLIZ, Oostende, $372 \mathrm{pp}$.

Volckaert A., Engledow H., Spanoghe G., Degraer S., Vincx M., Coppejans E. and Hoffmann M. (2003) Onderzoek van de seizoenale variatie van macroalgen, macrofauna en vogels geassocieerd met intertidale harde substraten langsheen de Vlaamse kust. Eindrapport in opdracht van het Min. Vlaamse Gemeenschap, Dept. Leefmilieu en Infrastructuur, Afd. Waterwegen en Zeewezen, $107 \mathrm{pp}$.

Wolff W.J. (2005) Non-indigenous marine and estuarine species in The Netherlands. Zoologische Mededelingen, Leiden 79, 1-116.

and

Woodwick K.H. (1963) Taxonomic revision of two polydorid species (Annelida, Polychaeta, Spionidae). Proceedings of the Biological Society of Washington 76, 209-215.

\section{Correspondence should be addressed to:}

F. Kerckhof

Royal Belgian Institute of Natural Sciences

Operational Directorate Natural Environment

Marine Ecology and Management Section 3e en 23e Linieregimentsplein, B-8400 Oostende, Belgium email: f.kerckhof@mumm.ac.be 